\title{
LEGALIDADE E DECISÕES POLÍTICAS
}

\author{
JoÃo ANTUNES DOS SANTOS NETO*
}

1. Introdução - 2. Administração e Governo - 2.1 Atos administrativos

- 2.2 Atos de Governo ou atos políticos - 2.3 As decisões políticas - 3 .

O Princípio da Legalidade - 3.1 O Período Intervencionista - $3.2 O$ Período do Estado Democrático de Direito - 3.3 Legalidade e discricionariedade - 3.3.1 Discricionariedade e circunstâncias excepcionais - 4 . Conclusões preliminares - 5. A(s) conclusão(öes) possivel(eis)

\section{Introdução}

Muito se discute na doutrina acerca das chamadas decisões políticas, sem aparente conciliação de idéias em relação ao tema. Não obstante, também dissonante se apresenta o posicionamento da comunidade científica (e mesmo das Cortes de Justiça) quanto à relação daquelas decisões políticas e o princípio da legalidade.

Longe de desejar esgotar as discussões quanto ao tema, o presente, ao contrário, tem por finalidade a busca de uma abordagem pessoal, traçada desde o desenvolvimento de algumas idéias extraídas do progresso de ambos os institutos, que vai considerar desde a evolução histórica do entendimento construído sobre seus matizes até a conformação de conceito próprio quanto à situação atual da problemática observada no debate proposto.

Destarte, para um melhor ordenamento do delineamento que se pretende fazer, de mister definir-se a relação da Administração Pública para com o princípio da legalidade, bem como o cotejo do que se convencionou chamar Governo e sua produção jurídica (atos ou decisões políticas ou de Governo) àquela relação de vinculação que tipifica e dá a cor dos traços e conotações do regime jurídico administrativo.

* O autor é Juiz de Direito no Estado de São Paulo, Professor Titular da Cadeira de Direito Administrativo da Faculdade de Direito de São Bernardo do Campo e Professor do Curso de Pós-Graduação em Direito Público da Escola Paulista da Magistratura. É mestre e doutorando em Direito do Estado (Direito Administrativo) pela Universidade de São Paulo.

R. Dir. Adm.,

Rio de Janeiro, 234: 147-175,

Out./Dez. 2003 
Todavia, antes de se debruçar sobre o assunto proposto, necessário estabelecerse a conceituação do que vem a ser Administração Pública e do que se considera Governo.

\section{Administração e Governo}

O estudo sugerido pede, contudo, que lhe seja antecedente a noção de Estado, que implica o reconhecimento de uma sociedade humana dotada de estrutura organizacional. Esta sociedade organizada é quem forma o embrião da idéia moderna de Estado que, por seu turno, tem conceito cambiante de acordo com o prisma de enfoque sobre sua magnitude; sociologicamente, é corporação territorial dotada de um poder de mando originário, conforme lição de Jellinek $k^{1}$ Tem o monopólio interno do uso da força, quando exercitada de forma legítima e não reconhece a superioridade de outra, no plano externo.

Todavia, até mesmo os sociólogos costumam caracterizar o Estado a partir da clássica definição de que o mesmo é uma sociedade politicamente organizada.

O Estado é uma sociedade politicamente organizada porque é uma comunidade constituída por uma ordem coercitiva, e "esta ordem coercitiva é o direito" 2 . O poder decorrente desta abstração é o poder do Direito, a eficácia do Direito Positivo, que dá ao Estado personalidade jurídica, tornando-o pessoa jurídica, organizada a partir de um Poder Constituinte ilimitado em qualquer sistematização normativa anterior, que pode mesmo rompê-la e inová-la.

Não obstante Kelsen ${ }^{3}$ discorrer largamente acerca do tema em desenvolvimento, basta-nos para o estabelecimento da idéia básica proposta pelo tema, a mentalização de que, a despeito de ser abstrato e inapreensível pelos sentidos, o Estado é pessoa sujeita de direitos e obrigações. A ele imputam-se ações com características humanas, que são consideradas atos do Estado, emanadas - conforme a lição do autor em epígrafe - de centros de competências designados "órgãos" 4 , e sempre correspondentes, de forma específica, à uma ordem jurídica pré-existente.

Diante destas premissas, aceitáveis sob o viés científico, podemos conceituar Estado, de modo conciso, como nação politicamente organizada e estruturada pelo Direito. É o Estado construído a partir da chamada "divisão de poderes" (que melhor se apresentaria como divisão de funções) pelo documento legal que lhe dá vida e regência sobre suas atividades. Tais poderes (seguindo-se a orientação acima traçada, de melhor alvitre seria qualificá-los de órgãos constitucionais), partindo-se da clássica teoria da tripartição, são instituídos e perfeitamente interligados com harmonia

1 JELLINEK, Georg, Teoría General del Estado. Trad. de Fernando de los Rios Urruti. Cidade do México, Editorial Continental S/A, 1956, pp. 312-354.

2 KELSEN, Hans, Teoria Geral do Direito e do Estado. Trad. de Luís Carlos Borges. São Paulo, Martins Fontes, 1995, pp. 191.

3 Op. cit., pp. 192 e segs.

4 Op. cit., p. 193. 
e equilibrio no que tange a seu funcionamento; nesta concepção, constituem o que se convencionou chamar Governo, que por sua vez não se confunde com Administração Pública, que seria, sob o prisma material, o próprio conjunto de serviços públicos em espécie (idéia solidificada desde a construção da teoria da separação dos conceitos de Governo e Administração).

Otto Mayer, ao empreender foco personalístico ao tema das funções tripartidas do Estado, sustenta que aquela situação (conjunto de atividades materiais desenvolvidas pelo Estado) consubstanciaria a Administração, desde que reconhecidas com autonomia e encaradas por seu conjunto; no desenvolvimento de seu pensamento, o autor afirma que Governo seria uma quarta espécie de atividade estatal, compreendida pela ciência política e não pelo Direito, conservando, em si próprio, uma natureza mais que tudo ideal, por "pertencer ao Príncipe e seus auxiliares e influir sobre todos os ramos da atividade material do Estado". Quanto a esta assertiva, valer trazer à conferência excerto de sua obra fundamental:

"Se dá, todavia, como quarta espécie de atividade, o governo (Rigierung). Mas o sentido da palavra 'governo', depois de haver passado por diferentes fases, se fixou na atualidade de uma maneira que o desaloja do círculo destes conceitos" 5 .

Atesta o pai do direito administrativo alemão, como Otto Mayer é cultuado, que Governo é alta direção, um cometimento que parte desde o centro para impulsionar assuntos referentes a uma boa política de interesse geral e coletivo.

Para outros doutrinadores, entretanto, Governo e Administração seriam sinônimos perfeitos. Daí a expressão "administrar é governar". Sustenta-se, a partir desta posição crítica, ser impossível estabelecer critério rigoroso para a separação entre os dois institutos. José Cretella Júnior ${ }^{6}$, com a propriedade que lhe é peculiar, esclarece que o Governo age por op̧̧ões políticas, enquanto a Administração procura proporcionar aos cidadãos as prestações continuadas de seus anseios em face ao Poder Público. Fá-lo, não sem lembrar que existem "políticas administrativas do Governo", as quais seriam as opções entre este ou aquele modo de administrar.

Para corrente intermediária, encabeçada por Maurice Hauriou, não mais haveria justificativa para a distinção entre uma e outra das funções decorrentes do exercício de Governo e Administração, apesar de o expoente gaulês separá-las uma da outra para o seguinte fim:

"A função Administrativa consiste, essencialmente, em realizar os problemas correntes do público. A função governamental consiste em resolver os

5 MAYER, Otto. Derecho Administrativo Alemán. Trad. de Horácio H. Heredia e Ernesto Krotoschin. Buenos Aires, Editora Depalma, 1949, p. 5.

6 CRETELla JÚNIOR, José. Manual de Direito Administrativo. Rio de Janeiro, Forense, 1989, p. 18. 
casos excepcionais que interessam à unidade política e a zelar pelos grandes interesses nacionais" 7

Gordillo, após tecer análise substanciosa entre o sistema político e o sistema jurídico e concluir pela garantia da constitucionalidade dos chamados atos de governo, sustentando a juridicidade de todas as ações estatais, radicaliza ao afirmar, de modo peremptório:

“(...) deve eliminar-se da linguagem e da técnica jurídica o nome e a teoria do 'governo' ou os 'atos de governo', 'atos políticos', 'atos não justiçáveis' etc., porque não respondem a uma instituição constitucionalmente válida, nem existem na realidade legislativa e jurisprudencial como um conceito de caracteres próprios ou de regime jurídico específico" 8

Enterría e Fernández, por outra via, dividem a produção estritamente administrativa da função política, de Governo, explorada pelo Estado. É da lavra dos expoentes do direito administrativo espanhol que:

"A consideração da Administração Pública como uma pessoa jurídica exige e, ao mesmo tempo, justifica a exclusão da mesma parte da atividade dos órgãos superiores de tipo político. Estes órgãos, especialmente o Governo, não são eventualmente órgãos da Administração Pública (aspecto sob o qual sua atividade está submetida ao Direito Administrativo), senão que cumprem, ademais, outras funções que nada tem que ver a Administração Pública enquanto pessoa. Assim ocorre, caracteristicamente, com os atos de caráter internacional, que não se imputam a Administração Pública interior, senão ao Estado global enquanto sujeito de relações internacionais, a quem o Governo representa, não estando submetidas por dita razão ao Direito Administrativo, senão, com maior propriedade, à Constituição $e$, nesse caso, ao Direito Internacional. É o pressuposto, também, dos atos constitucionais em que se baseiam as relações entre os Altos Órgãos do Estado (...)".

"O que sucede nestes casos é que aos titulares destes órgãos superiores da Administração Pública concorrem, ao mesmo tempo, a condição de comissionados do proprietário do poder', e a confiança' parlamentar em nosso sistema (...) para exercer dito poder. A concorrência dessa dupla condição explica que tais indivíduos atuem umas vezes enquanto titulares do órgão administrativo (em cujo pressuposto, sua atividade se imputa à Admi-

7 HAURIOU, Maurice. Précis de Droit Administratif et Droit Public. Paris, Recueil Sirey, 1911, p. 70 .

8 GORDILLO, Agustín A. Tratado de Derecho Administrativo. Buenos Aires, Ediciones Macchi-Lopez, 1975, T. I, pp. XIV 46-47. 
nistração como pessoa e está sujeita ao Direito Administrativo - todos os Regulamentos, atos e contratos administrativos procedentes do Conselho de Ministros) e outras, como pessoas que integram um centro de competências constitucionais como comissionados políticos do proprietário do poder' (em cujo caso sua atividade está submetida ao Direito Constitucional)" $"$.

Parece-nos ser esta acepção a mais próxima da realidade do que, de fato, modernamente ocorre. De um lado há a consideração de que realmente existem distintas funções exercidas pelo Estado, e que não se enquadram necessariamente na tipologia daquelas, formada pela trindade legislação, jurisdição e administração e que algumas vezes, de fato, parecem ser uma quarta atividade estatal. Outrossim, e aí se parte para uma visão global das ações estatais, pareceria não ser mais do que a somatória daquelas funções, só que em termos de alta gestão da coisa pública, pela pessoa jurídica Estado. Seria uma outra atividade por ele desenvolvida, altamente contaminada pelo elemento político. Neste diapasão, importante lembrar que a produção da dinâmica de Governo é diversa da chamada produção administrativa, vez que de uma derivam os atos políticos, os quais, justamente por esta natureza, não seriam, em tese, objeto de exame judicial, em sede de controle - salvo, segundo a melhor doutrina, quando promoverem lesão aos direitos individuais e aos chamados interesses difusos ${ }^{10}$.

Numa ótica mais abrangente, poder-se-ia mesmo aceitar que, após a assunção da teoria do Estado de Direito, seria impossível haver atividade estatal "extrajuridica" ou "suprajurídica" que impedisse a revisão de quaisquer atos estatais por quem tivesse a missão constitucional de fazê-lo ${ }^{11}$. Aliás, quanto a este tema específico, iremos retornar oportunamente, por ser ele imprescindivel ao desenvolvimento do pensamento que se tenciona construir.

Entretanto, apesar da profusão ideológica que o assunto permitiria colacionar e desenvolver, de se crer existir - até para o estabelecimento do raciocínio que desde o início se propõe - uma suposta divisão, ainda que tênue, entre as atividades governamental e administrativa propriamente dita, bastando por ora ressaltar que ambas, face à estruturação do Estado no Direito e pelo Direito se sujeitam ao controle constitucionalmente estabelecido, em face da dinâmica de sua produção; esta, não obstante, necessariamente tem de pautar-se pelo pré-disposto pela ordem normativa, a menos que se possa imaginar um Estado que decorra de outra ordem, paralela ao Direito.

9 ENTERRÍA, Eduardo García de; FERNANDES, Tomás-Ramón. Curso de Derecho Administrativo. Madri, Editorial Civitas, 1998, V. I, pp. 30-31.

10 DI PIETRO, Maria Sylvia Zanella. Direito Administrativo. São Paulo, Atlas, 2003, p. 56.

11 BANDEIRA DE MELLO, Oswaldo Aranha. Princípios Gerais de Direito Administrativo. Rio de Janeiro, Forense, 1969, V. I, p. 417. 
Uma daquelas atividades, pois, abrangeria a idéia ampla do termo administrar, face ao alto escalão da gestão política (De Governo); outra se compreenderia de forma estrita (administrativa).

Sustenta-se, da mesma forma, na doutrina, de modo a se tentar fixar linha divisória de águas entre os dois institutos em debate - tarefa mais do que árdua em razão da correlação existente entre ambos - que a Administração assume "posição de neutralidade ao executar políticas decididas por órgãos de representação política". Partindo desta idéia, Odete Medauar ${ }^{12}$ esclarece-nos que a "burocracia deve ser igualmente disponivel para executar quaisquer comandos políticos sejam quais forem os titulares do poder". Reafirma, com o pensamento transcrito, a idéia do caráter técnico e não político da atividade administrativa, não sem deixar de lembrar que, em dita sistemática, "se assegura à burocracia o exercício do poder político, sem a responsabilidade correspondente".

A aparente confusão entre Governo e Administração se dá, essencialmente, em razão da origem da produção observada na dinâmica de uma ou outra figura em testilha, a despeito de esta produção servir para diferenciar a atividade de um ou de outro instituto. Apontam os teóricos, de modo a praticamente consubstanciar a comunis opinium doctorum, que o vértice angular daqueles institutos é o Poder Executivo. Assim é que Gabino Fraga ${ }^{13}$, ao elucidar proposta de precisão de conceitos, crê ser necessário indicar que o Poder Executivo pode ser apreciado sob um duplo aspecto: como Governo ou Poder político e como Poder administrativo. No primeiro caso, se definiria pela situação que guarda dentro do Estado, com relação a este e aos demais Poderes em que se divide o exercício da soberania; no segundo, se resolveria pela relação com a lei que tem de aplicar e executar em casos concretos.

Não obstante, o grande mestre do direito público mexicano, ao assentir com a existência de uma atividade de Governo diversa da de Administração, adverte:

"Sem embargo, a admissão de sua existência não se deve entender como a admissão de uma nova categoria distinta das três outras desenvolvidas pelo Estado e que já foram objeto de estudo, pois o elemento novo que se encontra nos atos de governo, e que é sua finalidade, não afeta a natureza jurídica dos atos administrativos em cujas formas aqueles se manifestam ${ }^{14}$."

Conforme salientamos, a produção observada da atividade de Administração e aquela extraída da atividade de Governo, foi quem serviu de base para a sustentação da diferenciação dos institutos em tela. Os atos administrativos e os atos de Governo, ou atos políticos, foram móveis da repartição de que se trata e, portanto, estão a merecer melhor especificação.

12 MEDAUAR, Odete. O Direito Administrativo em Evolução. São Paulo, Revista dos Tribunais, 1992, p. 134.

13 FRAGA, Gabino. Derecho Administrativo. Cidade do México, Editorial Porruá, 1979, p. 65.

14 Op. cit., p. 65. 


\subsection{Atos administrativos}

No que tange aos atos praticados pela Administração Pública, enquanto pessoa jurídica de direito público, no exercício da função administrativa, é possível identificar uma categoria genérica e outras categorias específicas, derivadas da primeira. Assim, todo ato praticado no exercício daquela função (administrativa), é chamado de ato da Administração, compreendido na expressão os atos de direito privado e os atos materiais por ela praticados, como também os atos derivados da atividade de Governo, titulados de atos políticos. Da mesma forma, se esteiam na acepção dada à expressão, os atos que não ensejam demonstração de ação volitiva da Administração Pública (e que por esta razão não devam produzir efeitos jurídicos), os atos bilaterais (contratos), os atos decorrentes da atividade (poder) normativa conferida pela Constituição à Administração, e por fim, os atos administrativos propriamente ditos, espécie a qual, centra-se a atenção com mais especificidade, neste momento.

A despeito de o direito administrativo ser exorbitante e derrogatório do direito comum e mesmo refratário à maioria de suas regras, até para não se perder o norte traçado pela doutrina, que tão bem desenvolveu os conceitos básicos da ciência jurídica, por mais de um milênio, a partir do tronco ordinário de dogmas privatísticos, e permitir o desenvolvimento de qualquer ilação que se possa extrair a propósito do tema se faça sob a juridicidade, de se admitir como verdade estabelecida em bases insofismáveis o pensamento daqueles que vêem os atos administrativos como espécie do gênero ato jurídico, tendende a produzir os efeitos de criação, transferência, conservação, modificação ou extinção de relações jurídicas. José Cretella Júnior atenta para a conclusão lógica ao silogismo entabulado, afirmando que para a conceituação do que venha a ser ato administrativo, deve-se partir do conceito genérico de ato jurídico. Se este é toda manifestação lícita que tenha por objetivo imediato a aquisição, o resguardo, a transferência, a modificação e a extinção de direitos, o ato administrativo nada mais seria, na visão do autor, do que:

“(...) manifestação de vontade do Estado, por seus representantes, no exercício regular de suas funções, ou por qualquer pessoa que detenha nas mãos fração de poder reconhecido pelo Estado, que tem por finalidade imediata criar, reconhecer, modificar, resguardar ou extinguir situações jurídicas subjetivas, em matéria administrativa" ${ }^{15}$.

De um modo ou de outro, parece convergir a maioria absoluta dos estudiosos do assunto - e via de consequiencia, dos operadores do direito - que para a conceituação do ato administrativo típico, alguns traços são indispensáveis e integram mesmo a idéia do que seja a produção dinâmica do Estado, quando exteriorizada pela função administrativa. Assim é e resulta mesmo óbvio que a declaração de

15 CRETELLA JÚNIOR, José. Direito Administrativo Brasileiro. Rio de Janeiro, Forerıse, 1983, V. I, p. 4. 
vontade do Estado é necessariamente requisito essencial na formulação do conceito proposto, ao qual se integram, com proeminência, a produção de efeitos jurídicos imediatos, a sujeição a regime jurídico administrativo e a persecução do interesse público. Estes traços é que diferenciarão o ato administrativo típico de outros, exarados da atividade estatal plena, como também lhe conferirão atributos que lhe são específicos, decorrentes destas vicissitudes e que o particularizam entre seus similares, no plano jurídico do direito privado.

\subsection{Atos de Governo ou atos políticos}

Os atos de Governo, ou atos políticos, foram diferenciados, primordialmente, dos atos administrativos propriamente ditos em razão de uma peculiaridade: sua insindicabilidade. É fato histórico que a teoria dos atos políticos ou de Governo foi introduzida ao debate a partir de posição firmada pelo Conselho de Estado francês, num momento crítico da chamada Restauração bourbônica, quando a instituição, de criação napoleônica e, destarte, suspeita à nova ordem ungida ao poder, perigava mesmo quanto a sua existência. Naquela oportunidade o Conselho de Estado se negou a conhecer de reclamos que tinham relação a problemas políticos derivados da extinção do regime napoleônico, constituindo como das mais célebres de suas decisões nesse sentido o arrêt Laffite, de maio de $1822^{16}$. De se lembrar que anteriormente, especialmente no período pós-revolucionário, em virtude da rígida concepção empreendida à separação dos poderes, as contendas envolvendo a Adminis. tração eram por ela própria decididas, o que fez com que a consagração do contencioso administrativo como justiça, em fase posterior (primeiro império) só fosse encontrar a contradição afirmada que lhe poderia custar a sobrevivência com a Restauração (Monarquia dos Bourbons). Seguiu-se à decisão a que se fez menção uma série de outras, sempre com o mesmo fundamento, pelas quais o Conselho de Estado reafirmava a sua autolimitação em conhecer dos chamados atos políticos ou de Governo.

A partir destes precedentes, ensinam-nos Enterría e Fernández ${ }^{17}$, chegou-se à teoria do móvel político, segundo a qual, "fosse qual fosse o objeto material do ato, sempre que os governantes o ditassem em função de um fim político, o ato deixava de ser administrativo e se convertia em político, tornando-se, desta maneira, isento do controle contencioso-administrativo".

Esta orientação foi seguida até 1875 , quando se estabeleceu o sistema de jurisdição delegada (desde 1872), que reconheceu ao Conselho de Estado sua total independência. Pela primeira vez a teoria do móvel político foi rechaçada no julgamento do caso conhecido por arrêt Prince Napoleón e desde então se manteve a tese dos atos políticos ou de Governo unicamente - ainda segundo Enterría e Fernán-

16 MEDAUAR, Odete. Atos de Governo. In Revista de Direito Administrativo, Rio de Janeiro, Editora Renovar, jan./mar. De 1993, pp. 67-85.

17 Op. cit., V. I, p. 566. 
$\mathrm{dez}^{18}$ - "enquanto se referem a uma lista concreta de matérias, que a jurisprudência posterior foi reduzindo", lista esta que hoje é totalmente desvinculada da origem da doutrina (compreende, atualmente, as relações internacionais, as relações interconstitucionais entre o Executivo e os demais Poderes e as questões de graça e anistia).

Nada obstante haver diversos critérios apontados pela doutrina com o fim de fornecer a noção do que seja o ato político ou de Governo, a teoria descrita, da lista, parece contaminar a caracterização dita orgânica do instituto, pela qual aqueles atos advêm da autoridade ou órgão mais elevado do Executivo, ou decorrem diretamente da Constituição. Observe-se que há, num ou noutro caso - e esta observação se faz em consideração aos tempos posteriores à jurisprudência citada que listou os atos que se pode consagrar como de Governo ou políticos - assunção da lista, que, ou é alçada diretamente ao cânone constitucional, fazendo com que a atribuição da Constituição decorra (segunda hipótese descrita), ou do texto da Constituição indiretamente resulte (primeira hipótese, em razão das competências insertas, da mesma forma, na Carta). Assim como ocorreu o fenômeno da absorção das declaraçōes de direitos pelos textos constitucionais das nações tidas por civilizadas, a teoria da lista, decorrente da construção pretoriana originada do Conselho de Estado francês parece ter sido recepcionada pela mesma sistemática de assimilação em alguns países, em especial o Brasil.

Tecidas estas considerações e delineado, ainda que com as dificuldades que a matéria suscita, o ponto de diferenciação entre os atos administrativos e os chamados atos de Governo ou atos políticos, de se perquirir acerca do fundamento das decisões que precedem a expedição de ambos os tipos de provimentos. Estas decisões se confundiriam com os próprios atos que lhe são resultantes ou lhes seriam antecedentes? Se lhe são antecedentes qual seria sua natureza? Comum a ambos os tipos de atos, ou diferenciada, assim como o resultado das atividades da Administração e do Governo?

\subsection{As decisões políticas}

Decisão, que decorre do latim decisio e importa a idéia de diminuição, segundo o léxico, pode representar tanto o ato pelo qual uma autoridade decide após exame, quanto a escolha das orientações (de uma política, por exemplo). Do vernáculo, se formou a chamada teoria da decisão, que seria aquela teoria fundamentada na consideração conjunta de probabilidades e utilidades das diversas contingências em vista de uma tomada de decisão. Política, que decorre do grego politike, também tomada, a exemplo do que se fez com o vocábulo decisão, pela expressão lingüística da locução, pode significar tanto a ciência do governo dos povos ou direção de um Estado e determinação das formas de sua organização quanto maneira de os conduzir (os negócios do Estado).

Entretanto, para que a expressão possa resultar em conclusão aceitável do ponto de vista jurídico, de se tentar juridicizar aquilo que, a priori, poderia corresponder unicamente à ciência política. Se não o fizermos, seremos forçados a aceitar que no 
Estado existiriam forças, com poder de coerção, que independeriam do Direito para sua justificação, consistindo em atividade extrajurídica, metajurídica ou suprajuridica e que encontrariam legitimidade, ainda que sem vínculos com a lei em sentido amplo. Lei que, na expressão rousseauniana, consubstancia a expressão da vontade geral do povo, fonte de legitimação de todo o poder. Como já se teve a oportunidade de ressaltar anteriormente, após o advento do Estado de Direito não se justifica qualquer atividade estatal que não tenha respaldo jurídico. Caso contrário, outra não poderia ser a solução senão a radicalização, à maneira como se posicionam alguns autores, dentre os quais destaca-se Gordillo ${ }^{19}$. Deste modo, caminhando pelo fio condutor que desde o início se procurou firmar, de se absorver para a continuação do desenvolvimento da tese as sempre brilhantes lições de Diogo de Figueiredo Moreira Neto, que quanto ao tema, alías, nos leciona o seguinte:

"Posto que a Política é o exercício da alocação autoritária de valores", como nos ensina Easton, a ela caberá impregnar axiologicamente o poder. orientá-lo na prossecução dos fins e estabelecer os meios para que isto suceda. É na 'confluência constitucional' que políticos e juristas se encontram, para dar ao Poder do Estado sua feição positiva, construtiva e dignificadora" ${ }^{20}$. (grifos não originais)

Trazendo o significado das expressões para o mundo jurídico e, separando o ato decisório do ato de produção final da ação estatal - este considerado como aquele que produz efeitos jurídicos imediatos - e ainda tomando a dicção política como a maneira de condução dos negócios do Estado ${ }^{21}$ poder-se-ia identificar, então, sob o prisma científico, o antecedente lógico da produção da Administração e do Governo.

Identificado o móvel que antecede dita produção, talvez também fosse possível identificar, na origem, no tronco comum de ambas as atividades, as similaridades observadas entre os chamados atos administrativos e os atos de Governo ou atos políticos e, talvez, encontrar o fundamento das dificuldades que normalmente se deparam aqueles que decidem estudar o tema para a definição e diferenciação de um e de outro instituto.

O móvel que antecede dita produção se estabelece mediante instrumentos especialmente criados pelo Direito a esta finalidade. Estes instrumentos são as políticas de ação dos Governos. No dizer de Maria Paula Dallari Bucci ${ }^{22}$ as politicas seriam uma evolução à idéia de lei em sentido formal, "assim como esta foi uma evolução ao governement by men, anterior ao constitucionalismo. Eé por isso que se entende

19 C. f., p. 5, deste

20 MOREIRA NETO, Diogo de Figueiredo. Teoria do Poder. São Paulo, Revista dos Tribunais, 1992, pp. 28-29.

21 A noção de Estado, ainda que abreviada, já foi dada antecedentemente e consta do corpo do presente trabalho. C.f., p. 2, deste.

22 DALLARI BUCCI, Maria Paula. Direito Administrativo e Políticas Públicas. São Paulo, Saraiva, 2002, pp. 252-253. 
que o aspecto funcional inovador de qualquer modelo de estruturação do poder político caberá justamente às políticas públicas". Ao tecer comentários sobre a política contraposta à noção de princípios, a autora conclui, com o que concordamos, que a "crise do modelo normativista e dedutivo, em certa medida reducionista, leva a novos modelos de representação do direito, em que as técnicas de legislação e decisão não se baseiam mais exclusivamente em regras, mas também em princípios e objetivos".

Pelo que se denota, pois, a evolução do pensamento ora entabulado leva, como corolário lógico à resolução das questões formuladas intrinsecamente no início deste trabalho e expressamente demandadas ao final do item que antecede ao presente à discussão acerca da evolução do princípio da legalidade.

\section{O Principio da Legalidade}

O princípio da legalidade, como hoje é conhecido, é contemporâneo do Estado de Direito. Nasceu, entretanto, com o Estado Liberal, essencialmente ligado à idéia de limitação do poder. Em período anterior à Revolução Francesa, as técnicas de governo do absolutismo se lastreavam em premissas que atribuíam à pessoa do soberano a condição de escolhido de Deus, em razão do que concentrava em suas mãos a fonte de todo o Direito, coisa que lhe permitia atuar tanto por normas gerais e abstratas como por atos singulares que, inclusive, podiam contrariar aquelas. A Revolução rechaçou ambas as coisas e estabeleceu-se que a fonte do Direito não se encontraria em nenhuma instância supostamente transcendental à comunidade, senão nela própria, na sua vontade geral, que vinha consubstanciada na lei geral, que servia à determinação de cada um dos seus membros individualmente como também determinava cada um dos atos singulares do poder. Sobre o assunto, Enterría e Fernández ${ }^{23}$, em quem se buscou inspiração para o desenvolvimento do tirocínio anterior, afirmam que "toda organização política se apóia necessariamente em uma concep̧̧ão determinada do Direito e atua desde e em virtude da mesma".

No início, até pela conformação que se deu ao Estado, que adotou no periodo pós-revolucionário o modelo liberal, como se disse, observou-se que tanto aos particulares como para a Administração Pública bastava que se estabelece uma relação meramente compatível à lei. Isto decorreu da interpretação que se deu ao que vinha disposto, especialmente, pelo artigo $5^{\circ}$ da Declaração dos Direitos do Homem e do Cidadão de 1789, que prescrevia, in verbis:

“Art. $5^{\circ}$ - A lei não proíbe senão ações nocivas à sociedade. Tudo o que não é vedado pela lei não pode ser impedido e ninguém pode ou será forçado a fazer o que ela não ordena." 
A expressão Estado de Direito, por seu turno, foi construída pela dogmática alemã, no século XIX, e teve em Von Mohl seu grande expoente. Constituía ela a tradução literal de Rechtsstaat e foi difundida na França por Carrè de Malberg e, posteriormente, por seus discípulos da chamada Escola de Direito Público de Estrasburgo.

Segundo a melhor doutrina de Karl Larenz ${ }^{24}$ e Jean-Jacques Chevalier ${ }^{25}$, o objetivo perseguido era o de enquadrar e limitar o Poder do Estado pelo Direito. A teoria do Estado de Direito, exprimiria uma vontade de reforçar a juridicidade de um Estado inteiramente formado dentro do arcabouço do direito. O âmago da teoria do Estado de Direito se constitui no princípio segundo o qual os diversos órgãos do Estado não podem agir, senão em virtude de uma habilitação jurídica. Neste caso, o exercício de um poder se transforma em uma competência, instituída e enquadrada pelo Direito. A doutrina do Rechtsstaat conduz na prática à doutrina da lei sobre a Administração, de modo à dela se exigir que aja secundum legem (em virtude de uma habilitação legal) e não simplesmente que se abstenha de agir contra legem. Esta teoria, forjada na Alemanha durante a segunda metade do século XIX, restou, senão ignorada, ao menos pouco conhecida pelos franceses. Os primeiros desenvolvimentos que se consagraram datam de 1911, dos manuais de direito constitucional de Duguit e de Esmein. Estas obras, aliás, foram consideradas como marco inicial da transposição na França da tradição filosófica e política alemã acerca do poder.

Eles complementaram o pensamento de Carrè de Malberg e reconheceram sua contribuição à formação da Teoria Geral do Estado, pelo qual o conceito de Estado de Direito, tradução literal do termo alemão, foi utilizado. Fortemente influenciado pelo pensamento jurídico alemão, notadamente pelo exponencial publicista germânico Laband, a quem sucedeu na Cadeira de Direito Público da Faculdade de Direito de Estrasburgo depois da Primeira Guerra Mundial, Carrè de Malberg não se limitou a uma simples transposição - apesar da distancia entre um considerável número de elementos daquela teoria, inadaptáveis ao pensamento jurídico francês, ele construiu sua própria teoria do Estado de Direito, a qual confrontou ao direito positivo. A teoria em questão foi trazida à França com enxertos, sobre uma tradição política e institucional específica, herdada da Revolução, em relação àquela cujo estatuto é ambíguo. Ele contribui, assim, a fazer evoluir, em quotas substanciais de novos argumentos à crítica das instituições da Terceira República.

A construção de uma ordem jurídica hierarquizada era vista na França como o produto histórico da luta contra o absolutismo monárquico, visando a conter o poder real em ajustamento às normas superiores, nas quais ele deveria encontrar seu fundamento e seus limites.

Desde o início do século XX, contudo, aquela estrita hierarquização começa a ser abalada com o reconhecimento, pelo Conselho de Estado, da existência de um

24 LARENZ, Karl. Derecho Justo - Fundamentos de Etica Jurídica. Trad. de Luiz Díez-Picazo. Madri, Editorial Civitas, 1985, pp. 151-167.

25 CHEVALLIER, Jean-Jacques. LÉtat de Droit. In Revue du Droit Public et de la Science Politique en France et LÉtranger. Março/abril de 1988, V. 2, pp. 313-380. 
poder regulamentar autônomo em matéria de organização dos serviços e de polícia administrativa.

A supremacia da lei no seio da ordem jurídica se afirma ainda mais quando o Governo e a Administração vão estar progressivamente adstritos a um estrito respeito à legalidade, pelo fato do desenvolvimento de um verdadeiro controle jurisdicional sobre seus atos.

\subsection{O Periodo Intervencionista}

Em fins do século XIX se iniciaram reações contra o liberalismo, face das conseqüências negativas que produziu na ordem social. Observou-se uma expansão nas atividades do Estado, que na busca do equilíbrio social, passou a intervir na economia e no domínio privados, com o conseqüente acréscimo das atribuições estatais. Em razão destas vicissitudes, o Poder Executivo se fortalece e ganha a posição de preeminência inicialmente reservada ao Poder Legislativo. Uma nova abordagem da relação do Estado para com a lei se observa. Sustentam Enterría e Fernández ${ }^{26}$ que foram Kelsen (no plano teórico) e Merkl ("seu" administrativista) quem "puseram em marcha a primeira reação sistemática contra a explicação deficiente da legalidade da Administração". A concepção kelseniana, "hoje universalmente aceita", tomava por base que o processo de produção jurídica se executa paulatinamente a partir de uma norma fundamental e, na medida em que a Administração se insere em uma fase desse processo, não poderia atuar de outra maneira senão executando normas antecedentes, ainda que estas sejam ditadas por ela própria, como no caso dos Regulamentos. Merkl teria partido desse pressuposto, ao sustentar que não só a Administração está condicionada pela existência do Direito, senão também cada ação administrativa isolada estará condicionada pela existência de um preceito jurídico que admita ação semelhante. Opera-se, em razão da sedimentação desta doutrina, o princípio da "positive bindung", da vinculação positiva da Administração à legalidade, em substituição à concepção anterior da vinculação negativa ao mesmo princípio, que permitia à Administração, a exemplo do que ocorria ao particular, o estabelecimento de uma relação meramente compatível com aquele.

Charles Eisenmann comunga da mesma opinião, e afirma, quanto ao assunto em desenvolvimento:

"O princípio da legalidade evoluiu para a consideração de que a expressão não designava somente os atos emanados do Legislativo-Parlamento, mas também passou a abranger toda a manifestação normativa das mais diversas fontes - legalidade, como objeto, é, no mínimo, o conjunto de normas oriundas de fontes diversas" 27 .

26 Op. cit., V. I, pp. 430-431.

27 EISENMANN, Charles. Cours de Droit Administratif. Paris, LGDF, 1982, V. I, pp. 11-35. 
Quando da assunção ao chamado modelo do Estado Social de Direito, ao mesmo tempo em que houve modificação da abordagem até então compreendida da relação da Administração ao princípio da legalidade, observou-se uma situação de desequilíbrio político, vez que dotado de iniciativa legislativa e em razão de sua verdadeira predominância sobre os outros Poderes, o Poder Executivo, obrigado a "aumentar a sua complexidade interna", mantém a divisão de poderes apenas como "uma fachada formal" 28 .

Ao examinar as leis apenas em seu aspecto formal, o Poder Judiciário também se coloca em posição subalterna em face do Poder Executivo, dando ao controle que deveria ser o móvel que limitaria o abuso de poder do Estado em suas relações com os particulares, caráter meramente ritual, sem qualquer preocupação com as questões de fundo, em razão de sua desvinculação com os princípios de Direito Natural que serviram a alicerçar a estruturação do próprio conceito de Estado de Direito.

Chevallier $^{29}$, ao fazer referência a instrumentalização do Direito, que passa a ser "utilizado como meio pelo qual o Estado executa suas tarefas", adverte-nos que o "Estado prestador de serviços, coloca em segundo plano o problema dos limites do poder que constituíam as bases do Estado Liberal".

\subsection{O Período do Estado Democrático de Direito}

As situações observadas no período intervencionistas produziram consequiências indesejadas, derivadas do positivismo formalista kelseniano. A formulação do Estado Social passa por transformações e para que o insucesso de seu modelo não se perpetuasse passou-se a agregar a seu conceito novos elementos que pudessem the permitir a melhor promoção da chamada justiça social.

O principal desses novos elementos que se lhe introduziu foi o da participação popular; além da participação popular no processo político e no controle da Administração, ao povo foram disponibilizados instrumentos que o admitiam a influir diretamente nas decisões de Governo.

Além disto, reclamou-se, também, pelo retorno da legalidade ao conceito originário que serviu de base à formação da teoria do Estado de Direito. O Estado volta a se subordinar ao Direito e não à lei formal; a legalidade volta a encerrar a idéia de vinculação à lei e ao Direito, especialmente no que tange à sua base principiológica.

Guido Zanobini, ao enfrentar a problemática da relação da Administração com o princípio da legalidade na atualidade, se manifesta da seguinte maneira:

28 FARIA, José Eduardo. Eficácia Jurídica e Violência Simbólica. O Direito Como Instrumento da Transformação Social. São Paulo, Editora Universidade de São Paulo, 1988, p. 57.

29 CHEV ALLIER, Jean-Jacques. LÉtat de Droit. In Revue du Droit Public et de la Science Politique en France et LÉtranger. Março/abril de 1988, V. 2, pp. 313-380. 
"No estagio jurídico atual, os fins da Administração devem vir impostos pelo direito - sua atividade dever ser aquela que o direito prescreve ou consente" ${ }^{30}$.

Estas tendências, especialmente a de remessa do conceito de legalidade ao conceito de justiça, inspiraram diversas constituições de Estados contemporâneos. A Constituição Alemã, de 1949 trouxe prescrito em seu artigo 20 que "o poder legislativo está vinculado à ordem constitucional; os poderes executivo e judicial obedecem à lei e ao direito". As Constituições Portuguesa de 1976 e Espanhola de 1978 (que influenciaram sobremaneira o legislador constituinte brasileiro de 1988) trazem prescrições similares; a primeira, em seu artigo 266 a segunda em seu artigo 103.1, repetem as premissas germânicas apontadas, de modo que na Espanha a disposição da Carta é expressa no sentido de que a "os órgãos e agentes administrativos estão subordinados à Constituição e à lei e devem atuar com justiça $e$ imparcialidade no exercício de suas funções" 31 .

Importante lembrar, outrossim, que a evolução do conceito da legalidade concerne ao desenvolvimento da concepção do próprio Estado, afigurando-se essencial à compreensão do instituto as lições de Sérvulo Correia:

"A evolução da estrutura constitucional provoca modificações na posição funcional do princípio da legalidade e, deste modo, a alteração parcial do respectivo significado" ${ }^{32}$.

O autor também observa que em face da estruturação atual do Estado, o Direito representa, para efeitos de vinculação da Administração a seus mandamentos, não só a lei elaborada pelo órgão constitucional criado para esta finalidade, senão, também, aquela (lei) cuja competência para sua edição a Constituição (ou o Direito, considerado pelo prisma holístico) delegou. Vejamos, pois, sua exposição:

“Em diversos textos constitucionais, inclusive o português, distingue-se entre Administração do Estado e Administração autônoma. A ultima é composta por pessoas coletivas de direito público cujos órgãos representam todo um conjunto de indivíduos definidos em função da residência em determinado território ou da pertença a determinado setor profissional - a qualificação deste tipo de Administração como autônoma significa que as pessoas coletivas que a compõem não recebem orientação político-administrativa do Estado, extraindo-a antes da vontade democraticamente manifes-

30 ZANOBINI, Guido. LAttivitá Amministrativa et la Legge. In Scritti Vari di Diritto Publicce. Milāo, Dott A. Giuffrè, 1995, pp. 202/218.

31 DI PIETRO, Maria Sylvia Zanella. Discricionariedade Administrativa na Constituição de 1988. São Paulo, Atlas, 1.991, pp. 30-31.

32 SÉRVULO CORREIA, José Manuel. Legalidade e Autonomia Contratual nos Contratos Administrativos. Coimbra, Almedina, 1987, pp. 34. 
tada pelos seus membros. Num sistema constitucional assim, a lei do parlamento não representa a única forma de orientação da Administração pelo povo, uma vez que este a exerce também através de outras assembléias representativas, como as das regiões autônomas e das autarquias" ${ }^{33}$.

É certo, outrossim, que Estados Federados como o brasileiro, não possuem as peculiaridades dos Estados que se modelaram sob a ótica da centralização, a exemplo do português. Chega mesmo a soar estranho a nossos ouvidos a utilização das expressões regiões autônomas e autarquias, sendo certo que a referência às últimas apontam as chamadas autarquias territoriais, típicas dos Estados centralizados, cuja expressão designa, em breve apanhado, a falta de autonomia, mas a presença de auto-administração.

Peculiaridades quanto à organização interna dos Estados à parte, o certo é que o excerto do pensamento de Sérvulo Correia traz a lume questão de extrema relevância no estudo do princípio da legalidade. Dentre nós José Afonso da Silva ${ }^{34}$ a indica com agudez: a divisão daquele (princípio da legalidade) em dois princípios: o da prevalência da lei e o da reserva de lei.

O princípio da prevalência da lei consistiria na exigência de respeito a seus mandamentos e à vedação do desrespeito a seus comandos. $O$ princípio da reserva de lei, por seu turno, concerne a um conjunto de matérias constitucionalmente definidas que devem ser reguladas exclusivamente por lei, tida em seu sentido material e originada do órgão constitucional competente para editá-la, ainda que este órgão receba dita competência por delegação (que também deve ser constitucional). Sobre o assunto, aliás, Canotilho desenvolve preciso pensamento:

"Através do conceito da reserva de lei pretende-se delimitar um conjunto de matérias ou âmbitos matérias que devem ser regulados por lei. Esta reserva de matérias para a lei significa, logicamente, que elas não devem ser reguladas por normas jurídicas provenientes de outras fontes diversas da lei, p. ex. regulamentos. Existe reserva de lei sempre que a constituição prescreve que o regime jurídico de determinada matéria seja regulado por lei e só por lei, com exclusão de outras fontes normativas. A esta dimensão da reserva de lei acrescenta-se outra - a de que o Poder Executivo carece de um fundamento legal para desenvolver as suas atividades (reserva de lei como teoria da dependência do Executivo perante o Legislativo).

A reserva de lei não deve divorciar-se das estruturas constitucionais concretas de cada país, pois ela coloca problemas de delimitaçâo de competências que só em face dos ordenamentos constitucionais positivos podem ser esclarecidos. É diferente, assim, a problemática da reserva de lei em

33 Op. cit., pp. 42-43.

34 SILVA, José Afonso da. Curso de Direito Constitucional Positivo. São Paulo, Malheiros, 2001, p. 425 . 
um sistema constitucional de competências como o português, em que o Governo também possui poderes legislativos originários, e a problemática da reserva de lei numa ordem constitucional de competências em que o Executivo só dispõe de poderes legislativos quando autorizado pelo Parlamento. Não se pode esquecer que a reserva de lei depende da própria compreensão da ordenação de competências dentro dos arranjos organizatórios do poder político. Na realidade, a reserva de lei assume contornos diversos num sistema influenciado pela idéia de 'checks and balances' como o norte-americano ou num esquema de divisão de poderes (executivo, legislativo e judiciário) como, por exemplo, o alemão" 35 .

Uma vez fixados os parâmetros da legalidade, de se partir ao estudo da ação estatal, especialmente a administrativa, e sua conformação com o princípio. Para tanto, necessário se estabelecer seu cotejo com a discricionariedade, além de se promover a perquirição de sua similaridade com as chamadas decisões políticas.

\subsection{Legalidade e discricionariedade}

Quando a lei fixa de antemão todos os requisitos para a ação da Administração, no exercício de sua função, estabelecendo uma única solução possível em face do caso concreto, ocorre o que se convencionou chamar de vinculação. Nestas situações, a Administração desempenha um mero exercício de constatação entre a previsão da norma legal e os fatos que se apresentam em razão de uma ocorrência concreta; não lhe cabe, no exercício de atribuições com estas características, qualquer apreciação subjetiva precedente à expedição do ato ou tomada da decisão que, inclusive pode ser exigida pelo interessado, face da geração de direito público subjetivo que se consagra e que demanda a ação administrativa.

Entretanto, em razão da impossibilidade de o legislador prever, de forma exaustiva e anterior, todas as circunstâncias que exigem dita ação administrativa, permite-se, em determinados casos, que a Administração opere valoração subjetiva em razão de critérios de conveniência e oportunidade para o atendimento do interesse público no exercício de sua função; isto se convencionou chamar discricionariedade. Diante do caso concreto, quando a ação é discricionária, a Administração tem mais de uma alternativa a escolher na realização de sua dinâmica (exercício da função constitucional).

A discricionariedade, contudo, não pode ser confundida com arbitrariedade. A escolha que a lei deixa à Administração deve ser operada dentro do arcabouço jurídico. Inexiste discricionariedade para a opção entre o lícito e o ilícito, o legal e o ilegal; a discricionariedade implica liberdade de ação, de atuação, nos limites traçados pela lei e pelo Direito. Ultrapassados estes parâmetros a discricionariedade transforma-se em arbitrariedade, com a consequiência de a produção final observada ser inválida aos fins que se propõe.

35 CANOTILHO, José Joaquim Gomes. Direito Constitucional. Coimbra, Almedina, 1992, p. 798. 
Não obstante a doutrina moderna concordar com a definição que costuma ser dada ao que se convencionou chamar de discricionariedade, os escritos que se desenvolveram dedicados à análise do tema - e este debate tomou mais de meio século - não chegaram a um consenso; ao contrário, apontam para um leque de possibilidades. Num primeiro momento, a discricionariedade foi considerada em razão de sua insindicabilidade por parte do judiciário, visto que consistia numa atividade inteiramente reservada à Administração. Posteriormente a perspectiva muda e transforma o instituto num atributo peculiar da função administrativa, o que faz consentir seu exame, quanto à legitimidade do exercício daquela (função) em sede de controle jurisdicional. Villata, atento a esta vicissitude, concebe a discricionariedade da seguinte forma:

"Com o transcorrer dos anos, e com a individualização dos novos instrumentos de tutela jurisdicionais, a perspectiva muda - a discricionariedade transforma-se num modo de ser, um atributo peculiar da função administrativa que consente ao juiz o próprio exame de legitimidade, seja apenas assinalando o limite da cognição - além da regra que governava o exercício discricionário da função, segundo o princípio da razoabilidade" ${ }^{36}$.

Esta nova abordagem que se dá à discricionariedade afasta, em dado momento histórico, seu conceito daquele empreendido às chamadas decisões políticas, acerca das quais a doutrina insistiu (e insiste) em qualificar pelo "atributo" da insindicabilidade judicial. Entretanto, na concepção atual do instituto, a legitimidade que the contorna com as cores da legalidade, passa a ganhar uma amplitude diferente daquela tradicionalmente enfocada, especialmente pela doutrina positivista de influência kelseniana.

O conceito de legitimidade entrou no rol dos termos clássicos da teoria política após a famosa consideração de Max Weber sobre os três tipos de poderes legítimos. Legitimidade é, como a legalidade, um atributo do poder. Sob o prisma jurídico, ambos os institutos são sinônimos e indicam tudo aquilo que é conforme a lei. Bobbio $^{37}$, entretanto, atento às discussões que se desenvolveram pelos juristas acerca da real expressão das locuções em epígrafe, esclarece-nos que o termo legitimidade indicaria a "justificação do título do poder" e legalidade, seu "exercício".

Ao tecer monumentais considerações entre o paralelismo existente entre a justificação do poder e a justificação da norma jurídica, Bobbio não se surpreende com a afirmação da teoria de Kelsen, a qual considera o Poder e o Direito como faces distintas da mesma moeda. Acrescenta o autor que a justificação de um e de outro instituto se encontra a partir do prisma que se dê ao enfoque. Senão, vejamos:

36 VILlLATA, Riccardo. Diritto Amministrativo. In Obra Collettiva. Bolonha, 1998, p. 1.394.

37 BOBBIO, Norberto. Studi per una Teoria Generale Del Diritto. Torino, Giappichelli, 1970, pp. $79 / 93$. 
"O poder nasce da norma e produz norma; a norma nasce do poder e produz outros poderes. Um ordenamento jurídico na sua estrutura hierárquica pode ser visto como uma sucessão de normas se o considerarmos de baixo para o alto, isto é, do ponto de vista dos consociados nas suas mesmas aparências de governantes. Como uma sucessão de poderes, consideramos do alto para baixo, isto é, do ponto de vista dos mesmos consociados na aparência de governantes. Mas o ordenamento jurídico é considerado no seu complexo, um entrelaçado de normas que produzem poderes que produzem normas, $\mathrm{e}$ de normas que por sua vez dão vida a novos poderes. A teoria normativa do direito, na sua formulação mais divulgada, que é aquela kelseniana, deixa sombra em outra face da moeda, aquela do poder" 38 .

Na oportunidade em que faz a sustentação colacionada, Bobbio ${ }^{39}$ conclui que na norma fundamental é que se vai determinar, pelo ordenamento jurídico, o poder - a summa potestas - fazendo ver que, além de um "poder último", com o qual se prendem as doutrinas tradicionais, existe ainda uma "norma última" que lhe serve de fundamento, razão pela qual uma norma, não um poder, seria o fundamento originário da legitimidade. "A norma fundamental é pura e simplesmente o teto que faltava, ou se acreditava faltar, ao edifício de um sistema normativo".

Nada obstante a conclusão do autor partir ao enfrentamento da eficácia do exercício do poder como seu relevo essencial, até mesmo para que se mantenha o raciocinio sob o feixe que iluminou o caminho de todo o adiantamento do presente, desde o inicio, preferimos justificar que o poder que funda a norma fundamental (ela fundamenta o poder e necessita de um poder para fundamentá-la) é aquele poder originário, que no Estado Democrático de Direito encontra justificação na democracia (é o poder popular o único legítimo a fundar a Constituição que legitimará o exercício do poder).

Partindo-se, pois, do arquétipo construído para a significação de legalidade, defendemos, juntamente com Enterría e Fernánde $z^{40}$ que ela é quem define e atribui, "com normalidade, potestades à Administração". E a ação da Administração é o exercício destas potestades. A atribuição legal de potestades ou poderes administrativos corresponde à vinculação (quando a atribuição reduz a ação administrativa a uma constatação) ou à discricionariedade (inclusão no processo de uma estimação subjetiva da própria Administração), faculdade esta que dimana do ordenamento e não pode operar-se fora do arcabouço jurídico, pois.

E a atribuição de poderes à Administração que decorre do ordenamento pode tanto ser expressa como implícita; esta última procede da consideração do significado atual do princípio da legalidade, conforme se expôs e que remete à idéia de lei e de Direito. Sendo este último formado não só pelo conjunto de leis formais, mas especialmente pelos principios, que se estabelece uma condensação dos grandes

40 Op. cit., V. I, p. 437. 
valores jurídicos materiais que constituem o substrato do ordenamento, se prestam não só como fonte de atribuição de poderes como também em limites objetivos da ação administrativa a empreender. Enterría e Fernández ampliam nossos horizontes, ao esclarecer a consistência dos princípios:

"Consistem (os princípios) na expressão de uma justiça material especificada tecnicamente em função dos problemas jurídicos concretos e objetivada na própria lógica das instituições" 41 .

A partir destas premissas, podemos entender com normalidade que a atribuição de potestades pode decorrer, também, da iniciativa da própria Administração; é o que parte da doutrina entende por auto-atribuição legítima de poderes, face do uso de suas competências legais para fazê-lo. Nestas circunstâncias, ela (Administração) pode tanto inovar no mundo jurídico em razão de conjunturas excepcionais (casos de calamidades públicas ou que demandem ação urgente para a manutenção da ordem econômica e social do Estado e da Sociedade) ou mesmo em situações coloquiais, de mera execução da lei, por meio dos Regulamentos. De se notar que nestas situações não se observa quebra do princípio da legalidade, senão "uma confirmação do mesmo enquanto mecanismo formal" complementam Enterría $e$ Fernánde $\mathrm{z}^{42}$, ao considerar que o poder regulamentar é potestade atribuída de modo prévio pelo ordenamento ao órgão encarregado do exercício da função, nos limites de sua competência.

Eros Grau comunga desta opiniäo e sustenta, com a peculiar maestria:

“Há visível distinção entre as seguintes situações: vinculação da Administração às definições da lei; vinculação da Administração às definições decorrentes, isto é, fixadas em virtude dela - de lei. No primeiro caso estamos diante da reserva de lei; no segundo, em face da reserva da norma (norma que pode tanto ser legal quanto regulamentar, ou regimental).

Na segunda situação, ainda quando as definições em pauta se operem em atos normativos não da espécie legislativa - mas decorrentes de previsão implícita ou explícita em atos legislativos contida -, o princípio estará sendo devidamente acatado. No acaso, o princípio da legalidade expressa reserva da lei em termos relativos (= reserva da norma), razão pela qual, no exercício não impede a atribuição explícita ou implícita ao Executivo para, no exercício da função normativa, definir obrigação de fazer ou de não fazer que se imponha aos particulares - e os vincule" ${ }^{43}$.

41 Op. cit., V. I, p. 466.

42 Op. cit., V. I, p. 466.

43 GRAU, Eros Roberto. O Direito Posto e o Direito Pressuposto. São Paulo, Malheiros, 2000, pp. 183-184. 
De todo o exposto se extrai que, o exercício de qualquer potestade (especialmente a discricionária), não importa a técnica de atribuição, resulta de uma relação de conformidade com o princípio da legalidade. Este, por seu turno, não pode ser entendido de maneira restrita à lei formal, senão, em concepção mais ampla, que lhe aproxima do devido processo legal em sua faceta substantiva, o que força ao reconhecimento de que aquela relação de conformidade mencionada - da positive bindung de Merkl - que a ele (princípio da legalidade) vincula a Administração de forma positiva, concerne mais que tudo à submissão do administrador ao Direito, ao próprio ordenamento juridico considerado sob o prima holístico, aos princípios, e não à norma escrita ritual, apenas.

Entretanto, a flexibilidade que esta relação de conformidade outorga a ação administrativa, ainda assim de conformidade será; nunca, nem mesmo nos casos de auto-atribuição de potestades, poder-se-ia falar em mera compatibilidade com a legalidade, situação que somente os particulares podem ostentar frente ao princípio, por serem os titulares de seus próprios interesses. A Administração (e o Estado, por quê não?), por não ter a titularidade dos interesses que tutela, só pode agir autorizada explicita ou implicitamente pela ordem juridica e tomando-se a legalidade na forma como descrita. Mais que isto, não se pode desconsiderar da lei o atributo de a mesma constituir a expressão da vontade geral do povo, vontade externa esta que se impõe a quem administra o poder.

\subsubsection{Discricionariedade e circunstâncias excepcionais}

Os conceitos de discricionariedade e de legalidade encontram entorno bastante interessante quando do acontecimento das chamadas circunstâncias excepcionais. Rivero ${ }^{44}$ define-as como aquelas que autorizam a Administração a infringir as leis as quais deveria normalmente curvar-se. Isto ocorreria em face de certas situações de crise, quando o respeito pela legalidade teria o efeito de paralisar a atividade administrativa, "impedindo-a de tomar as medidas necessárias, ou retardando-as". A justificativa seria, segundo o autor, a escolha necessária que o administrador deve fazer entre a eficiência e o respeito pela lei. Salienta, entretanto, que "os atos praticados nessas circunstâncias, embora por um lado escapem à legislação ordinária, nem por isso estão menos submetidos ao direito: somente estão submetidos a um direito especial, distinto daquele que se aplica em tempo normal".

Comungam da mesma opinião outros autores, dentre os quais destaca-se Chapus, para quem, em face da excepcionalidade de certas situaçōes, o próprio conceito de legalidade é que será observado sob ótica mais elástica. Sobre o assunto, é da lavra do citado jurista:

" $O$ direito não existe por si mesmo. Existe para o fim de organização da vida social. O legislador, bem como o juiz, devem ser sensiveis à necessidade

44 RIVERO, Jean. Direito Administrativo. Trad. de Rogério Ehrhardt Soares. Coimbra, Almedina, 1981, p. 99. 
de liberar, em certas circunstâncias, as autoridades administrativas da obrigação de observar as regras que regem normalmente sua ação. $O$ princípio da legalidade é em conseqüência adaptado de diversas maneiras aos fatos que as circunstâncias podem levar ao habitual" ${ }^{45}$.

Tanto Rivero como Chapus citam como exemplo de circunstâncias excepcionais $a$ guerra, $o$ estado de sítio $e$ o estado de emergência, além sas situações de calamidade pública em geral. Aliás, a teoria em comento foi consagrada primordialmente em decisão do Conselho de Estado francês de 28 de junho de 1918 que se baseou nas condições em que se exerciam os poderes públicos durante a guerra.

Sem embargo de as técnicas de controle diferenciarem-se, especialmente no espaço, face da realidade constitucional particularizada de cada um dos Estados que compõem a comunidade internacional, parece-nos certo que a teoria das circunstâncias excepcionais adequa-se à lista de matérias que foi formada para indicar os chamados atos de Governo ou atos políticos aos quais já se teve a oportunidade de discorrer anteriormente.

Todavia, se faz necessário, por ser absolutamente pertinente, colacionar a matéria neste momento para que alguns pontos sejam conectados. Os atos de Governo ou atos políticos, para sua expedição, dependem de avaliação subjetiva por parte da autoridade que os expede e, neste diapasão, podem (e devem) ser tratados como discricionários.

Recebendo esta qualificação, a eles aplica-se toda a sorte de consequiências cabíveis às decisões administrativas, especialmente a sujeição à legalidade, considerada em seu plano global, vez que a relação da ação do Estado continua sendo de conformação ao princípio em tela. De se notar, que algumas Constituições, como a brasileira, promulgada em 1988, trazem rol de matérias que poderiam consubstanciar a chamada ação de Governo, nos moldes em que foi concebida pelo Conselho de Estado francês (construção iniciada a partir do arrêt Prince Napoleón), vinculando o exercício a seus mandamentos expressos ou implícitos e sujeitando-as a controle pelo Legislativo (art. 49, IV, art. 84, VIII, XIX e XX), a quem cabe apreciar o mérito de ditas decisões. Além disto, o Judiciário também exercerá a sindicância desses provimentos, em razão da impossibilidade de exclusão do conhecimento de quaisquer atos que impliquem violação ou ameaça de violação a direitos (art. $5^{\circ}, \mathrm{XXXV}$ ).

De outro lado, poder-se-ia contestar a afirmação sob a justificativa de que qualquer decisão estatal no exercício de qualquer de suas funções, seria derivada da discricionariedade exercida pelo elemento humano (agente) que integra o órgão público, centro de atribuição do poder (legislativo, executivo ou judiciário) na forma do permitido pelo ordenamento, fazendo com que aquela qualidade de ações encontrasse guarida na definição ordinária dos atos administrativos típicos, atos jurisdicionais típicos ou atos legislativos típicos. Porém, as decisões políticas, face da classificação que receberam e continuam a receber, poderiam ser consideradas em um gênero à parte, escapando daquela formatação, justamente por sua qualificação 
(de Governo ou políticas), em razão das teorias que se construíram acerca de sua existência, o que faria permitir concluir, falsamente, pela possibilidade de guardarem como característica a insindicabilidade, face da maior amplitude discricionária que concentram, derivada da ação programática, de cunho político que antecede o exercício funcional.

\section{Conclusões preliminares}

Primeiramente, parece-nos incorreto, ou ao menos impreciso, imaginar que as decisões políticas ou de Governo consubstanciem somente aquelas emanadas das autoridades mais elevadas do Executivo. Mesmo levando em consideração as "conseqüências externas do ato" $e$ os "destinatários" 46 que o mesmo visa alcançar, como também a decorrência direta de atribuição constitucional para sua prática, ainda assim, não se poderia excluir o Legislativo e o Judiciário como possíveis protagonistas da ação política.

Quanto ao Legislativo não se encontraria dificuldade em imaginar a situação descrita, vez que sua produção é essencialmente política. O Judiciário, contudo, nunca aparece nas citações como pólo produtor de ações políticas ou governamentais, o que nos aparenta um equívoco. Isto porque, partindo do pressuposto que a ação governamental encerra a compreensão de que "realmente existem distintas funções exercidas pelo Estado, e que não se enquadram necessariamente na tipologia daquelas, formada pela trindade legislação, jurisdição e administração e que algumas vezes, de fato, parecem ser uma quarta atividade estatal", o que exigiria a compreensão de que "para uma visão global das ações estatais, pareceria não ser mais do que a somatória daquelas funções, só que em termos de alta gestão da coisa pública, pela pessoa jurídica Estado" "47, não nos pareceria haver critérios válidos à luz da ciência jurídica que excluísse da ação de Governo aquela empreendida pelo Judiciário.

A ação governamental da qual decorrem as chamadas decisões políticas seria uma outra atividade desenvolvida pela pessoa jurídica Estado com a característica de ser "altamente contaminada pelo elemento político". Portanto, o Judiciário, constituido como órgão elementar daquela pessoa jurídica (Estado), justamente por esta condição, não poderia ser excluído do que se convencionou chamar de Governo; destarte, corolário lógico, também não poderia deixar de tomar decisões que não fossem qualificadas de políticas.

$\operatorname{Heras}^{48}$, ao discorrer sobre a falta de base cientifica da teoria da tripartição dos poderes, assume de maneira implícita o esposado - a despeito de excluir, ao final de seu pensamento, as ações empreendidas pelo Judiciário daquelas que entende que

46 FIORINI, Bartolome. Apud MEDAUAR, Odete. Atos de Governo. In Revista de Direito Administrativo, Rio de Janeiro, Editora Renovar, jan./mar. De 1993, pp. 67-85.

47 C. f. p. 6, deste.

48 HERAS, Jorge Xifras. El Gobierno e la Función Política. In Dirección General del Servicio Jurídico del Estado. Instituto de Estudios Fiscales (org.). Madrid, 1998, pp. 1.843-1.851. 
constituem ações de Governo - ao sustentar que "a multiforme atividade estatal não se pode dividir em setores bem diferenciados e os órgãos não podem desenvolver atividades exclusivas de uma função concreta - os atos administrativos, legislativos, judiciais e politicos seguirão mantendo seu caráter essencial seja qual for o órgão do qual procede ou o tratamento jurídico que merece".

Face desta assertiva, não se poderia excluir o Judiciário do Governo e, conseqüentemente, não se poderia deixar de considerar que alguns de seus atos consubstanciam decisões políticas, ora materializadas em decisões jurisdicionais ou administrativas praticadas pelo órgão - sob o aspecto extrínseco -, ora qualificadas mesmo externamente, como atos de Governo típico. Exemplo das primeiras seria a declaração de constitucionalidade ou de inconstitucionalidade de leis (ação desenvolvida no exercício da função jurisdicional), ou a escolha por um ou outro meio de prestação de sua atividade (por exemplo, a decisão administrativa interna de criação de varas especializadas em determinada comarca). Este último exemplo se encaixa na visão de Heras $^{49}$ quando sustenta que as ações de Governo consubstanciam o "efetivo o princípio unitário diretor da orientação política" e se adequa, da mesma forma, ao que Maria Paula Dallari $\mathrm{Bucci}^{50}$ qualifica por políticas públicas, considerada à luz do Direito como "programa de ação". Quanto à segunda hipótese aventada, podemos citar os atos de direção política exterior também praticados pelo Judiciário, quando representa o Estado perante delegações estrangeiras ou participa de esforços conjuntos entre Estados soberanos de modo a satisfazer o principio da cooperação, vigente no direito internacional, no uso de suas competências exclusivas ${ }^{51}$.

Também nesta categoria de atos com feição política sob os aspectos intrínseco e extrínseco, poder-se-ia incluir as hipóteses previstas nos artigos 34 , inciso IV, e 36, incisos I, II, III e IV, previstos na Constituição brasileira. Os dispositivos tratam da intervenção federal mediante requisição do Poder Judiciário. Lewandowski ${ }^{52}$, ao discorrer acerca desta situação, sublinha, com brilhantismo, que "recebida a requisição de que cuida o dispositivo constitucional sob análise, o Presidente da República estará obrigado a intervir, porquanto se trata, nesse caso, de uma competência

49 Op. cit., p. 1.848.

50 Op. cit., p. 253.

51 Recentemente, o Judiciário brasileiro deu prova de que age nesse sentido. As eleições majoritárias no vizinho país do Paraguai se realizaram mediante a utilização de urnas eletrônicas brasileiras. Como a cessão destas urnas depende, exclusivamente, da decisão da cúpula da mais elevada Corte Eleitoral do Brasil, não se poderia excluir o conteúdo político de dita decisão, com reflexos nas relações entre Estados soberanos, exercida na competência constitucional que lhe foi outorgada, que não é jurisdicional ou administrativa típica. Após o episódio, o Governo colombiano iniciou tratativas com o "Judiciário brasileiro" no sentido de também obter o empréstimo das urnas nas eleições que deveriam se realizar naquele país. Para tanto, noticiaram os meios de comunicação, o Presidente do Superior Tribunal Eleitoral do Brasil dirigiu-se à Colômbia de modo a implementar a cooperaçāo entre os Estados, na forma pretendida.

52 LEWANDOWSKI, Enrique Ricardo. Pressupostos Materiais e Formais da Intervenção Federal no Brasil. São Paulo, Revista dos Tribunais, 1994, pp. 36-37 e 126-127. 
vinculada, ou seja, não permite o juízo de conveniência e oportunidade quanto ao seu exercício". Isto ocorre porque, ainda segundo o autor, "a análise do estado de coatividade ou impedimento já foi previamente realizada pelos Tribunais Superiores". Em outra passagem de sua obra, Lewandowski debate as teses que se formaram acerca da natureza jurídica do ato de intervenção. Esteiado em André de Laubaderè, José Afonso da Silva e em Pontes de Miranda, sustenta com solidez que a intervenção federal é, essencialmente, um "ato político ou um ato de governo, caracterizado pela ampla discricionariedade, inobstante seja empreendido para a consecução de fins constitucionalmente pré-ordenados".

Como no caso de intervenção, a requisição não pode ser desatendida pelo Presidente da República, sob pena de cometimento de crime de responsabilidade. Nada obstante, cabendo aos Tribunais Superiores a análise prévia dos pressupostos daquela (requisição), parece-nos claro que a decisão política ou de Governo é tomada pelo Judiciário, a quem se defere a ampla discricionariedade decisória que tipifica aqueles tipos de provimentos; ao Presidente da República, caberá, in casu, mera execução do reclamo sustentado em permissivo legal (vale lembrar que quem requisita reclama em nome da lei; não solicita, eis que as expressões não são sinônimas).

Já no que tange à somatória das funções estatais - oriunda da trindade legislação, jurisdição e administração - como expressão da atividade governamental e acerca da qual já se teve a oportunidade de discorrer, observamos, que também na estrutura constitucional brasileira, dois exemplos marcantes existem da caracterização política da ação conjunta dos órgãos que compõe a cúpula da pessoa jurídica Estado. Assim ocorre quanto à previsão da iniciativa conjunta do Presidente do Supremo Tribunal Federal, do Presidente da República, do Presidente do Senado e do Presidente da Câmara dos Deputados para a fixação dos subsídios dos Ministros do Supremo Tribunal Federal (art. 48, XV) e quanto ao julgamento, por crimes de responsabilidade, cometidos pelo Presidente e pelo Vice-Presidente da República, bem como pelos Ministros de Estado e pelos Comandantes da Marinha, Exército e Aeronáutica, pelos Ministros do Supremo Tribunal Federal, pelo Procurador Geral da República e pelo Advogado Geral da União, que é da competência privativa do Senado Federal, presidido, entretanto, naquelas circunstâncias, pelo Presidente do Supremo Tribunal Federal (art. 52, I e II, com a redação de seu parágrafo único).

Entretanto, mesmo compreendendo a possibilidade da deteç̧ão das vicissitudes apresentadas, é de mister ser considerado com ênfase, da mesma forma, o pensamento de Rivero ${ }^{53}$, que entende ser muito difícil demarcar a fronteira entre os domínios do que vem a ser Governo $e$ do que vem a ser Administração. A reflexão por ele esposada dá-nos a idéia da contaminação da política nas decisões administrativas, especialmente quando formula a demanda seguinte: a nomeação de um alto funcionário terá alcance governamental se indica uma mudança política, ou terá significado puramente administrativo? Podemos, com o permissivo da amplitude do pensamento transcrito, transplantar a questão ao exercício da jurisdição: terá uma decisão

53 Op. cit., p. 17. 
judicial alcance governamental, se indicar uma mudança política, quando, por exemplo, invalidar a nomeação de um Ministro de Estado em razão de suas incompatibilidades pessoais ao exercício das funções inerentes ao cargo, ou quando decretar a constitucionalidade ou a inconstitucionalidade de uma lei, ou tais decisões terão significado puramente jurisdicional?

Aparenta-nos, finalmente, que em todas as circunstâncias apontadas, a ação do Judiciário implica participação nas decisões da alta gestão dos interesses do Estado e não pode deixar de ser considerada sob o plano político, consubstanciando, desta forma, o que se convencionou chamar de decisões políticas ou atos de Governo.

Esta conclusão preambular responde, até onde lhe é possível, às indagações formuladas anteriormente no corpo deste trabalho. No entanto, não são suficientes a encerrar de modo conclusivo as sustentações construídas.

\section{A (s) conclusão (óes) possível (eis)}

Estabelecidas as premissas e delimitações quanto ao que se pode entender por decisões políticas ou de Governo, a primeira conclusão possivel a que se chega é a de que qualquer uma daquelas decisões, indistintamente, submetem-se ao princípio da legalidade, considerado na acepção que lhe contornou a estruturação democrática do Estado de Direito. Esta garantia de legalidade é, pois, ínsita de uma garantia genérica, que Gordillo ${ }^{54}$ qualifica, com precisão, em "garantia de constitucionalidade". Este posicionamento, aliás, se adequa ao pensamento de $\mathrm{Bobbio}^{55}$, o qual se teve a oportunidade de colacionar. Se esta garantia não pode ser abandonada às leis, pois sua constitucionalidade e juridicidade são o primeiro parâmetro que elas (leis) devem seguir, com maior propriedade se aplicam à "qualquer ato emanado de uma autoridade pública", esteja ela no exercício de qualquer atividade estatal, inclusive a governamental, que não pode, sob nenhuma justificativa aceitável pelo Direito, ser separada das demais para qualquer finalidade.

Do mesmo modo e pelas mesmas razões, não se justifica mais a manutenção da tese da insindicabilidade das decisões políticas ou de Governo em face da amplitude do conceito da legalidade, como em determinado momento histórico não mais se justificou a manutenção da tese quanto à discricionariedade das decisões administrativas.

Destarte, exige-se, como também se exige das leis, que as decisões governamentais sejam razoáveis e proporcionais, de modo a integrar o sistema jurídico que lhes legitima.

A fim de que o sistema de legalidade seja, de fato, eficaz, as decisões políticas ou de Governo devem se submeter não só ao controle legislativo, mas, também, ao controle popular, realizado, inclusive especialmente em sede jurisdicional, posto que esta seria a única justificativa à expressão que qualifica o Estado como pessoa 
sujeita de direitos e obrigações, a quem se imputam ações com características humanas, que são consideradas atos do Estado, emanados de centros de competências designados "órgãos", e sempre correspondente, de forma especifica, conforme se pode extrair das lições de Kelsen ${ }^{56}$, "à uma ordem jurídica pré-existente”.

Fora desta ordem jurídica, não há ação governamental que seja válida; numa ótica mais abrangente, só seria aceitável, após a assunção da teoria do Estado de Direito - conforme, além do mais, o legado deixado por Oswaldo Aranha Bandeira de $\mathrm{Mello}^{57}$ - a inexistência de possibilidade de haver atividade estatal "extrajurídica" ou "suprajurídica" que "impedisse a revisão de quaisquer atos estatais por quem tivesse a missão constitucional de fazê-lo".

Mesmo no caso das chamadas circunstâncias excepcionais, a premissa se apresenta verdadeira, visto que a vinculação à legalidade permanece, entretanto, subordinada a uma legalidade diferente da habitual. Também o ato essencialmente político de declaração do início do estado de anomalia que reconhece a ocorrência das circunstâncias excepcionais deve guardar correlação com o pré-disposto no ordenamento, sob pena de ser tida por inválida em sede de revisão judicial, possivel a esta finalidade. Assim, sob o prisma de estruturação juridica do Estado Democrático de Direito, a solução razoável (e possível) é a da conformação da ação estatal à juridicidade, em todos os seus contornos.

\section{BIBLIOGRAFIA}

ARAÚJO CINTRA, Antonio Carlos de. Motivo e Motivação de Ato Administrativo. São Paulo: Dissertação de Concurso à Livre Docência de Direito Administrativo da Faculdade de Direito da Universidade de São Paulo, 1978.

BOBBIO, Norberto. Studi per uma Teoria Generale Del Diritto. Turim: Giappichelli, 1.970 .

CANOTILHO, José Joaquim Gomes. Direito Constitucional. Coimbra: Almedina, 1.992.

CHAPUS, René. Droit Administratif General. Paris: Montchrestian, 2001.

CHEVALIER, Jean-Jacques. LÉtat de Droit. Revue du Droit Public et la Science Politique em France et lÉtranger. Paris: 1988 (mar./abr.).

CRETELLA JUNIOR, José. Tratado de Direito Administrativo. Rio de Janeiro: Forense, 1966/1972.

Direito Administrativo Brasileiro. Rio de Janeiro: Forense, 1983.

Manual de Direito Administrativo. Rio de Janeiro: Forense, 1989.

DALLARI BUCCI, Maria Paula. Direito Administrativo e Políticas Públicas. São Paulo: Saraiva, 2002.

DEVOLVÉ, Pierre; VEDEL, Georges. Droit Administratif. Paris: Presses Universitaires de France: 1980.

56 Op. cit., p. 193.

57 Op. cit., V. I, p. 417. 
DI PIETRO, Maria Sylvia Zanella. Direito Administrativo. São Paulo: Atlas, 2003. Discricionariedade Administrativa na Constituição de 1988. São Paulo: Atlas, 1991.

EINSENMANN, Charles. Cours de Droit Administratif. Paris: LGDF, 1982.

ENTERRÍA, Eduardo García de; FERNÁNDEZ, Tomás-Ramón. Curso de Derecho Administrativo. Madrid: Editorial Civitas, 1998.

FARIA, José Eduardo. Eficácia Jurídica e Violência Simbólica. O Direito Como Instrumento de Transformação Social. São Paulo: Editora Universidade de São Paulo, 1988.

FERNÁNDEZ, Tomás-Ramón; ENTERRÍA, Eduardo García de. Curso de Derecho Administrativo. Madrid: Editorial Civitas, 1998.

Arbitrariedad y Discrecionalidad. Madrid: Civitas, 1991.

FIGUEIREDO, Lúcia Valle. Discricionariedade: poder ou dever? In: Curso de

Direito Administrativo. São Paulo: RT, 1986.

Curso de Direito Administrativo. São Paulo: Malheiros, 1999.

FRAGA, Gabino. Derecho Administrativo. México: Editorial Porruá, 1979.

GIANNINI, Massimo Severo. Diritto Amministrativo. Milano: Dott A. Giuffré, 1970.

GIUFFRÈ, Felice. Declino Del Parlamento Legislatore ed Coscita del Potere de Inchiesta. LABRIOVA, Silvano (org.). La Autoritá Independetti. Milão: Dott.

A. Giuffrè, 1999.

GORDILlO, Agustín A. Princípios Gerais de Direito Público. São Paulo: RT, 1977. Tratado de Derecho Administrativo. Buenos Aires: Macchi-López, 1975.

La Administración Paralela. Madrid: Civitas, 1982.

GRAU, Eros Roberto. Direito Posto e Direito Pressuposto. São Paulo: Malheiros, 2000.

HAURIOU, Maurice. Précis de Droit Administratif et Droit Public. Paris: Recueil Sirey, 1911.

HERAS, Jorge Xifras. El Gobierno y la Función Pública. Madri: Instituto de Estudios Fiscales, 1998.

JELLINEK, Georg. Teoria General Del Estado. México: Editora Continental S/A, 1956.

KELSEN, Hans. Teoria Geral do Direito e do Estado. São Paulo: Martins Fontes, 1995.

LARENZ, Karl. Derecho Justo - Fundamentos de Etica Política. Madri: Civitas, 1985.

LEWANDOWSKI, Enrique Ricardo. Pressupostos Materiais e Formais da Intervenção Federal no Brasil. São Paulo: Revista dos Tribunais, 1994.

MAYER, Otto. Derecho Administrativo Alemán. Buenos Aires: Depalma, 1949.

MEDAUAR, Odete. Direito Administrativo Moderno. São Paulo: RT, 2003.

Direito Administrativo em Evolução. São Paulo: RT, 1992.

A Processualidade no Direito Administrativo. São Paulo: RT, 1993.

Atos de Governo. Revista de Direito Administrativo. Rio de Janeiro: Editora Renovar, 1993 (jan./mar.). 
MELLO, Oswaldo Aranha Bandeira de. Principios Gerais de Direito Administrativo. Rio de Janeiro: Forense, 1969/1974. 2 v.

MERKL, Adolf. Teoria General deI Derecho Administrativo. México: Editora Nacional, 1980.

MOREIRA NETO, Diogo de Figueiredo. Legitimidade e Discricionariedade. Rio de Janeiro: Forense, 2001.

Teoria do Poder. São Paulo: RT, 1992.

MORTATI, Costantino. Instituzioni di Diritto Pubblico. Padova: Cedam - Casa Editrice Dott. Antonio Milani, 1975.

RIVERO, Jean. Direito Administrativo. Coimbra: Almedina, 1981.

SALAVERRÍA, Juan Igartua. Princípio de Legalidad, Conceptos Indeterminados y Discrecionalidad Administrativa. Civitas Revista Española de Derecho Administrativo. Madri: Editora Civitas, $\mathrm{n}^{\circ}$ 92, 1996.

SÉRVULO CORREIA, José Manuel. Legalidade e Autonomia Contratual nos Contratos Administrativos. Coimbra: Almedina, 1987.

SESIN, Domingo. Administración Pública. Actividad Reglada, Discrecional y Técnica. Buenos Aires: De Palma, 1994

SILVA, José Afonso da. Curso de Direito Constitucional Positivo. São Paulo Malheiros, 2001.

VEDEL, Georges; DEVOLVÉ, Pierre. Droit Administratif. Paris: Presses Universitaires de France, 1980.

VILLATA, Ricardo. Diritto Amministrativo. Bolonha: Obra Colletiva, 1998.

ZANOBINI, Guido. Corso di Diritto Amministrativo. Milano: A. Giuffrè, 1968.

LAttivitá Amministrativa ed la Legge. Scritti Vari di Diritto Publicce. Milão:

Dott. A. Giuffrè, 1995. 


\section{Instituições Financeiras e Mercado de Capitais}

\section{Jurisprudência - Tomo I}

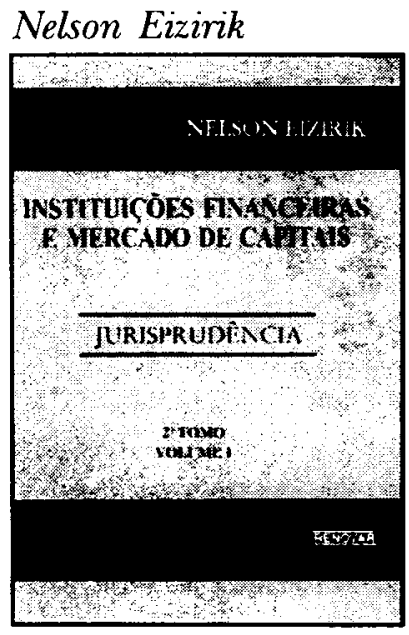

A presente obra é fruto de trabalho de pesquisa que reúne a jurisprudência dos tribunais brasileiros sobre instituições financeiras e mercado de capitais, no periodo de 1986 a 1994. Trata-se, a nosso ver, de obra que pode ser de grande utilidade para estudantes, advogados, membros do Poder Judiciário e todos aqueles, no exercício de atividade profissional, necessitam ter acesso imediato à jurisprudência de nossos tribunais em matéria de Sistema Financeiro.

Ref. 0109

Form. 16x23

Cartonado

2 volumes

1.840 págs.

1996

\section{Instituições Financeiras e Mercado de Capitais} Jurisprudência - Tomo II

Nelson Eizirik

A presente obra dá continuidade ao livro "Instituiçōes Financeiras e Mercado de Capitais - Jurisprudência", publicado em 1996 por esta mesma Editora. No presente volume estão reunidos os acórdãos dos tribunais brasileiros sobre instituiçōes financeiras e mercado de capitais, no período de 1994 a 1997.
Ref. 0187
Cartonado
Form. 16x23
2 vols.
1.655 págs. 1998

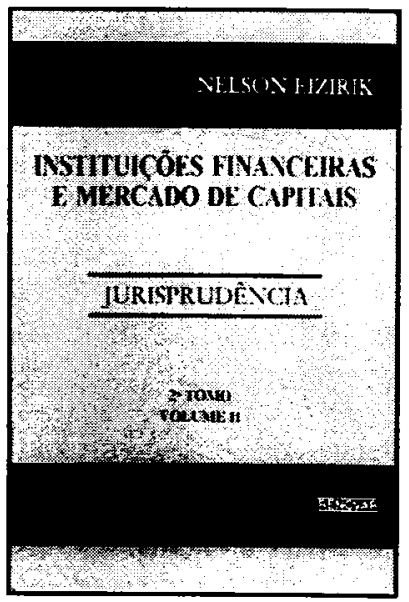

